\title{
ANTS OBTAINED FROM TREES OF A "JACAREÚBA" (Calophyllum brasiliense) FOREST PLANTATION IN CENTRAL AMAZONIA BY CANOPY FOGGING: FIRST RESULTS
}

\author{
Ana Yoshi HARADA', Joachim ADIS ${ }^{2}$
}

\begin{abstract}
Canopies of the locally occurring Amazonian tree specics Calophyllum brasiliense Camb. (Guttiferae, height $10 \mathrm{~m}$ ) were fogged after dawn on the same day at five adjacent localities in a 20-year-old plantation at the Adolpho Ducke Forest Reserve near Manaus/Brazil, using natural pyrethrum $(0.5 \%, 1.0 \%, 1.5 \%)$, Baythroid $(0.3 \%)$ and diesel oil, respectively. The 1152 ants collected represented 52 species, 17 genera and five subfamilies. The highest number of ant species was obtained with the synthetic pyrethrum Baythroid $0.3 \%$ and with natural pyretbrum $1.5 \%$. About $46 \%$ of the total ant species were only collected in the first hour after fogging, and $17 \%$ only during the second hour, after trees had been heavily shaken. About $73 \%$ of the total ant specimens dropped in the first hour. Data on alpha-diversity, eveness and frequency of ants indicated a rapidly decreasing knock-down effect of both the synthetic and natural pyrethrum after application. The ant fauna in the canopy of $\mathrm{C}$, brasiliense is somewhat distinct compared with that of Goupia glabra Aubl. (Celastraceae, height $45 \mathrm{~m}$ ) from the primary forest of the reserve.
\end{abstract}

Key Words: ants, canopy fogging, pyrethrum, forest plantation, Amazon, Neotropics.

Formigas Obtidas de Árvores numa Plantação de "Jacareúba" (Calophyllum brasiliense) na Amazônia Central Através da Nebulização de Copas: Primeiros Resultados.

RESUMO - As copas de uma espécie de árvores de ocorrência local, Calophyllum brasiliense Camb. (Guttiferae, altura 10m), foram nebulizadas depois do amanhecer do mesmo dia, em cinco localidades adjacentes, numa plantação com 20 anos de idade na Reserva Florestal Adolpho Ducke perto de Manaus/Brasil, usando-se piretro natural $(0,5 \%, 1,0 \%, 1,5 \%)$, Baythroid $(0,3 \%)$ e óleo diesel, respectivamente. As 1152 formigas coletadas representaram 52 espécies, 17 géneros e cinco subfamilias. O maior número de espécies de formigas foi obtido com o piretro sintético Baythroid $0,3 \%$ e com pítetro natural 1,5\%. Cerca de $46 \%$ de todas as formigas foram coletadas somente na primeira hora depois da nebulização, e $17 \%$ somente durante a segunda hora, depois das árvores serem fortemente sacudidas. Cerca de $73 \%$ de todos os individuos de formigas cairam durante a primeira hora. Dados sobre a alfa-diversidade, uniformidade e frequência de formigas indicam um rápido efeito decrescente de caida, tanto do piretro sintético quanto do piretro natural depois da sua aplicação. A fauna de formigas na copa de C. brasiliense de certa forma e distinta em comparação com a fauna de Goupia glabra Aubl. (Celastraceae, altura $45 \mathrm{~m}$ ) da floresta primária na reserva.

Palavras chave: formigas, nebulização de copas, piretro, plantação de floresta, Amazônia, Neotrópicos.

\section{INTRODUCTION}

Ants represent in most cases the dominant arthropod taxon in the canopies of Central Amazonian forests (Adis \& Schubart, 1984; Adis et al., 1984; Erwin,
1983, 1989; Harada \& Adis, 1997).

A total of 100 species and $2 i$ genera were obtained from the canopy of Goupia glabra Aubl. (Celastraceae; common name "Cupiuba") in Central Amazonia during the dry and rainy sea-

\footnotetext{
'Museu Paraense Emilio Goeldi, Departamento de Zoologia, Caixa Postal 399, 66.040-170, Belém, Pará, Brazil.

${ }^{2}$ Max-Planck-Institute for Limnology, Tropical Ecology Working Group, Postfach 165, D-24302 Ploen, Germany.
} 
sons (Harada \& Adis, 1997). Wilson (1987) found 43 species representing 21 genera on a single tree in Western Amazonia.

This contribution is concerned with the knock-down efficiency of natural and synthetic pyrethrum, as well as of diesel oil, in a forest plantation of Calophyllum brasiliense Camb. (Guttiferae; common name "Jacareúba") in Central Amazonia during the rainy season. In addition, data on ant richness, frequency and species similarity among plots are given.

\section{STUDY SITE AND METHODS}

The study area (Adolpho Ducke Forest Reserve) belongs to the National Institute for Amazonian Research (INPA), and is located about $26 \mathrm{~km}$ northeast of Manaus (02 $\left.55^{\prime} \mathrm{S}, 59^{\circ} 59^{\prime} \mathrm{W}\right)$. This reserve has been intensively studied for more than 20 years (e.g. Willis, 1977; Penny \& Arias, 1982; Adis \& Schubart, 1984; Adis, 1988; Hero, 1990; Prance, 1990; Höfer et al., 1994; Adis et al., 1997).

The ants and other arthropods were sampled from the canopy in a 20 year-old forest plantation of the locally occurring tree species Jacareúba (Calophyllum brasiliense Camb., Guttiferae) during the rainy season (February, 1992) with fogging (for details see Adis et al., 1997).

In five selected plots, each covering an area of $32 \mathrm{~m}^{2}$ and about 50 $\mathrm{m}$ apart, the tree canopies were fogged from the ground at the same time at dawn of the same day. The trees were about $10 \mathrm{~m}$ in height, the diameter of the tree trunks was about $16 \mathrm{~cm}(\mathrm{dbh})$ and canopy diameter was about $4 \mathrm{~m}$.
The five plots were fogged for 3 minutes with $0.5 \%, 1.0 \%$ and $1.5 \%$ natural pyrethrum (diluted in diesel oil; without synergist), the synthetic pyrethrum Baythroid $(0.3 \%$, diluted in diesel oil; with synergist) and diesel oil, respectively. The knockdown effect of the killing agent Baythroid was stated by the manufacturer (Bayer, Leverkusen /Germany, personal communication) to be 10 times more effective than that of the non-killing natural pyrethrum. A sixth plot served as control and was not fogged. For each plot the falling ants were collected in six funnel-shaped trays as described in Adis et al. (1997). The trays were randomly distributed along horizontally extended ropes within the plots. Ants were collected for 1 hour after fogging, the trees on all plots were then heavily shaken and ants were collected for a further 1 hour. In this way, the efficiency of the knock-down agent used for canopy fogging could be evaluated. Due to technical problems, the fogging machine produced only a weak fog in the plot treated with $1 \%$ natural pyrethrum.

\section{RESULTS AND DISCUSSION}

\section{Knock-down efficiency of insecti- cides.}

About $73 \%$ of all ants $(n=1152)$ dropped in the first hour after fogging and the remaining $27 \%$ within sixty minutes after the trees had been shaken (Fig. 1). The highest number of ant species collected in each of the 1 hour drop periods was obtained with the synthetic pyrethrum Baythroid $0.3 \%$ ( $\mathrm{n}=19$ and 12 species), followed by natural pyrethrum $1.5 \% \quad \mathrm{n}=18$ and 7 species; Figs. 2-4, 7). The highest 
relative abundance of ants (54 ind. $/ \mathrm{m}^{2}$ ) was observed in the plot treated with pyrethrum $0.5 \%$ due to a nest of Crematogaster sp. \#3 in the canopy. The knock-down effect of diesel oil was lowest and comparable with the control plot, with regard to both species number and abundance of ants (Figs. 2-4). The relatively low drop rates of ants obtained with natural pyrethrum $1.0 \%$ (Fig. 4) are attributable to technical problems during fogging.

\section{Species richness, frequency and taxonomic composition.}

The 1152 ants collected represented 52 species, 17 genera and five subfamilies (Myrmicinae, Formicinae, Dolichoderinae, Ponerinae and Pseudomyrmecinae; Tab. 1, Fig. 1). Species richness was highest in the Myrmicinae (33 species of 7 genera), the Formicinae (17 species of 5 genera) and the Dolichoderinae ( 8 species of 3 genera; Tab. 1). Similar results were obtained by Wilson (1987) in Peru and by Harada \& Adis (1997) in Central Amazonia.

The most common genera were Camponotus (10 species), Crematogaster (7 species), Dolichoderus (4 species), Procryptocerus (4 species), Zacryptocerus (4 species), and Solenopsis (4 species; Tab. 1). Results are comparable with those for ants fogged from the canopy of Cupiuba in the same forest reserve (Harada \& Adis, 1997).

Twenty-four out of 52 species $(46.2 \%)$ were solely collected in the first hour after fogging, and 9 species $(17.3 \%)$ only during the second hour, after trees had been shaken (Tab. 1, Fig. 1).

The cumulative number of species obtained from 35 collecting trays
(Fig. 5) indicated that at least 25 trays were necessary to obtain most of the ant species from the canopy of the Jacareúba plantation, covering $192 \mathrm{~m}^{2}$ of ground. Only 18 collecting trays were sufficient to collect the ant species of two Cupiuba trees in the same reserve (Harada \& Adis, 1997). These two trees represented the uppermost canopy of the forest: they had a crown diameter of $14 \mathrm{~m}$ and $15 \mathrm{~m}$, covering an area of about $331 \mathrm{~m}^{2}$, and a height of $38 \mathrm{~m}$ and $45 \mathrm{~m}$, respectively.

The higher alpha-diversity of ants found one hour after fogging and before shaking trees, as well as their higher eveness and lower frequency observed 60 min after shaking of trees (Tab. 2, 3; Fig. 7) suggest that the knock-down effect of both synthetic and natural pyrethrum decreased rapidly after application. Further interpretation of the indices will only be possible after the fogging experiment has been repeated.

Only 21 ant species $(21 \%)$ obtained from the canopy of the Jacareúba plantation during the rainy season in 1992 were found in common when compared to the 100 ant species fogged from the two Cupiuba trees during the dry and rainy seasons 1991/ 92 (cf. Table 17.1 in Harada \& Adis, 1997). Only $37 \%$ of the ant species were the same as those obtained from the two Cupiuba trees fogged during the rainy season in $1992(n=51)$. Data indicate that the ant fauna in the canopy is, to a large extent, distinct in both the Jacareúba plantation and the Cupiuba trees. Differences might be due for example to the different height of the two tree species and the monoculture effect. This has to be confirmed by 
Table 1. Ant species obtained from the canopy of a Jacareúba (Calophyllum brasiliense) forest plantation near Manaus/Brazil during the rainy season (February, 1992). 1st = catch $60 \mathrm{~min}$ after fogging and before shaking trees; 2 nd = catch $60 \mathrm{~min}$ after shaking trees; $\Sigma=$ total catch.

\begin{tabular}{|c|c|c|c|}
\hline Ant species & $1 s t$ & 2nd & $\sum$ \\
\hline \multicolumn{4}{|l|}{ Subf. Dolichoderinae } \\
\hline Azteca \#2 & 4 & $\ldots$ & $\begin{array}{l}2 \\
4\end{array}$ \\
\hline Azteca \#3 & 21 & 1 & 22 \\
\hline Dolichoderus bidens & 92 & 25 & 117 \\
\hline Dolichoderus bispinosus & 5 & 3 & 8 \\
\hline Dolichoderus haradae & 52 & 15 & 67 \\
\hline Dolichoderus lutosus & 1 & $\ldots$ & 1 \\
\hline Tapinoma sp. \#1 & 1 & $\cdots$ & 1 \\
\hline \multicolumn{4}{|l|}{ Subf. Formicinae } \\
\hline Acropyga sp. \#1 & 1 & $\cdots$ & 1 \\
\hline Acropyga sp. \#5 & 1 & $\cdots$ & 1 \\
\hline Camponotus alboannulatus & 1 & 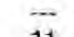 & 1 \\
\hline Camponotus bidens & 72 & 11 & 83 \\
\hline Camponotus brasiliensis & 1 & $\ldots$ & 1 \\
\hline Camponotus butoni & $\cdots$ & 1 & 1 \\
\hline Camponotus nr. fastigatus & 1 & $\ldots$ & 1 \\
\hline Camponotus godmani & -. & 1 & 1 \\
\hline Camponotus iridis & 1 & $\ldots$ & 1 \\
\hline Camponotus latangulus & 2 & 1 & 3 \\
\hline Camponotus pittieri & 1 & $\ldots$ & 1 \\
\hline Camponotus trapezoideus & 2 & $\ldots$ & 2 \\
\hline Dendromyrmex chartifex & 1 & $\ldots$ & 1 \\
\hline Myrmelachista sp. \#3 & 29 & 11 & 40 \\
\hline Myrmelachista sp. \#4 & 5 & 2 & 7 \\
\hline Myrmelachista sp. \#5 & 1 & - & 1 \\
\hline Paratrechina sp. \#12 & - & 2 & 2 \\
\hline \multicolumn{4}{|l|}{ Subf. Myrmicinae } \\
\hline Crematogaster sp. \#1 & 3 & ... & 3 \\
\hline Crematogaster sp. \#2 & 8 & $\Rightarrow$ & 8 \\
\hline Crematogaster sp. \#3 & 362 & 96 & 458 \\
\hline Crematogaster $\mathrm{sp} . \# 7$ & 63 & 52 & 115 \\
\hline Crematogaster sp. \#8 & 32 & 51 & 83 \\
\hline Crematogaster $\mathrm{sp} . \# 10$ & 4 & 5 & 9 \\
\hline Crematogaster sp. \#12 & 7 & 8 & 15 \\
\hline Cyphomyrmex striagatus & 1 & 2 & 3 \\
\hline Leptothorax brasiliensis & $\ldots$ & 2 & 2 \\
\hline Leptothorax (N.) sp. \#2 & 1 & $\cdots$ & 1 \\
\hline Procryptocerus clathratus & $\ldots$ & 1 & 1 \\
\hline Procryptocerus cf. gracilis & 1 & $\cdots$ & 1 \\
\hline Procryptocerus pictipes & 5 & 2 & 7 \\
\hline Procryptocerus subpilosus & 2 & ... & 2 \\
\hline Solenopsis sp. \#10 & 17 & $\cdots$ & 17 \\
\hline Solenopsis sp. \#17 & 1 & $\cdots$ & 1 \\
\hline Solenopsis sp. \#18 & 25 & 11 & 36 \\
\hline Solenopsis sp. \#19 & 1 & 1 & 2 \\
\hline Zacryptocerus laminatus & 2 & 1 & 3 \\
\hline Zacryptocerus notatus & $\ldots$ & 1 & 1 \\
\hline Zacryptocerus simillimus & - & 2 & 2 \\
\hline Zacryptocerus solidus & $\cdots$ & 1 & 1 \\
\hline \multicolumn{4}{|l|}{ Subf. Ponerinae } \\
\hline Pachycondyla nr. arhuaca & 1 & - & 1 \\
\hline Pachycondyla crenata & 4 & $\rightarrow$ & 4 \\
\hline Platythyrea angusta & 1 & $\cdots$ & 1 \\
\hline \multicolumn{4}{|l|}{ Subf. Ṕseudomyrmecinae } \\
\hline Pseudomyrmex gracilis & 2 & $\overline{1}$ & 2 \\
\hline Pseudomyrmex terminalis & 2 & 1 & 3 \\
\hline Number of individuals & 840 & 312 & 1152 \\
\hline Number of species & 43 & 27 & 52 \\
\hline Number of genera & 16 & 12 & 17 \\
\hline
\end{tabular}


Table 2. Richness of species and diversity indices of ants obtained by fogging the canopy in a Jacareúba (Calophyllum brasiliense) forest plantation near Manaus/Brazil during the rainy season (February, 1992). $1 \mathrm{st}=60 \mathrm{~min}$ after fogging and before shaking trees; $2 \mathrm{nd}=60 \mathrm{~min}$ after shaking trees.

\begin{tabular}{|c|c|c|c|c|c|c|c|c|c|}
\hline \multirow[t]{2}{*}{ Sample } & \multirow[t]{2}{*}{ S } & \multirow[t]{2}{*}{$\mathrm{N}$} & \multirow[t]{2}{*}{ A } & \multirow[t]{2}{*}{ D } & \multirow[t]{2}{*}{$\mathrm{H}_{\mathrm{s}}$} & \multirow[t]{2}{*}{$E$} & \multirow[t]{2}{*}{ Dominant species } & \multicolumn{2}{|c|}{ Density } \\
\hline & & & & & & & & $\mathrm{sp}$. & Total \\
\hline 1st & 43 & 840 & 9.6 & 0.22 & 3.18 & 0.59 & $\begin{array}{l}\text { Crematogaster \#3 } \\
\text { Dolichoderus bidens } \\
\text { Camponotus bidens }\end{array}$ & $\begin{array}{c}10.34 \\
2.63 \\
2.06\end{array}$ & 24.03 \\
\hline 2nd & 27 & 312 & 7.1 & 0.16 & 3.27 & 0.69 & $\begin{array}{l}\text { Crematogaster \#3 } \\
\text { Crematogaster \#7 } \\
\text { Dolichoderus bidens }\end{array}$ & $\begin{array}{l}2.74 \\
1.49 \\
1.46\end{array}$ & 8.94 \\
\hline
\end{tabular}

$\mathrm{S}=$ number of species

$\mathrm{N}=$ number of specimens

Eveness: $E=H_{s} / H_{\max }$ (Pielou)

$\mathrm{A}=$ alpha index

Diversity: $D=1-1 p^{2}$ (Simpson)

$\mathrm{H}_{\max }=\log \mathrm{S}$

Density $=\mathrm{ind} / \mathrm{m}^{2}$

$H_{t}=-p_{1} \log _{2} p_{i}$ (Shannon-Wiener)

Table 3. Richness of species and frequency indices of ants obtained by fogging the canopy in a Jacareúba (Calophyllum brasiliense) forest plantation near Manaus/Brazil during the rainy season (February, 1992). $i \mathrm{st}=60 \mathrm{~min}$ after fogging and before shaking trees; $2 \mathrm{nd}=60 \mathrm{~min}$ after shaking trees.

\begin{tabular}{|c|c|c|c|c|c|c|c|c|c|}
\hline \multirow[t]{2}{*}{ Sample } & \multirow[t]{2}{*}{$S$} & \multirow[t]{2}{*}{$\mathrm{N}$} & \multirow[t]{2}{*}{ A } & \multirow[t]{2}{*}{ D } & \multirow{2}{*}{$\mathrm{H}_{\mathrm{s}}$} & \multirow[t]{2}{*}{$E$} & \multirow[t]{2}{*}{ Dominant species } & \multicolumn{2}{|c|}{ Density } \\
\hline & & & & & & & & sp. & Total \\
\hline \multirow[t]{3}{*}{$1 \mathrm{st}$} & 43 & 122 & 24.9 & 0.06 & 4.73 & 0.87 & Crematogaster $\# 3$ & 0.34 & 3.28 \\
\hline & & & & & & & Dolichoderus bidens & 0.34 & \\
\hline & & & & & & & Camponotus bidens & 0.40 & \\
\hline \multirow[t]{3}{*}{ 2nd } & 27 & 72 & 15.5 & 0.06 & 4.35 & 0.92 & Crematogaster \#3 & 0.29 & 2.08 \\
\hline & & & & & & & Crematogaster $\# 8$ & 0.20 & \\
\hline & & & & & & & Dolichoderus bidens & 0.17 & \\
\hline
\end{tabular}

$\mathrm{S}=$ number of species

$\mathrm{N}=$ number of frequencies

$A=$ alpha index

Diversity: $\quad D=1-1 p^{2}$ (Simpson)

$H_{s}=-p_{1} \log _{2} p_{1}$ (Shannon-Wiener)

refogging the Jacareuba canopy during the rainy and dry seasons of different years. In addition, the number of terricolous ant species which temporarily forage in the lower canopy should be determined.

\section{ACKNOWLEDGEMENTS}

This study is part of a 6-year project on 'Mechanisms that maintain tropical diversity', funded by the German Research Foundation, the German Agency of Technical Cooperation (GTZ: project
Eveness: $\mathrm{E}=\mathrm{H}_{c} / \mathrm{H}_{\max }$ (Pielou)

$\mathrm{H}_{\text {max }}=\log \mathrm{S}$

Density $=$ ind $/ \mathrm{m}^{2}$

85.2522.2-06100) and the Brazilian Research Foundation (CNPq: project $\mathrm{CNPq}$ / MPG 91.0304/90-4) since 1991. Sincere thanks are expressed to PD Dr. W.J. Junk and Dr. Maria Teresa Fernandez Piedade for logistical support in Manaus via the 'Projeto INPA/Max-Planck'. We heartily thank all scientists of the diversity project and of INPA, especially Dr. Claudio Ruy $\mathrm{V}$. da Fonseca, the technical staff of INPA as well as the participants of the postgraduate course 'Entomological Field Ecology' 


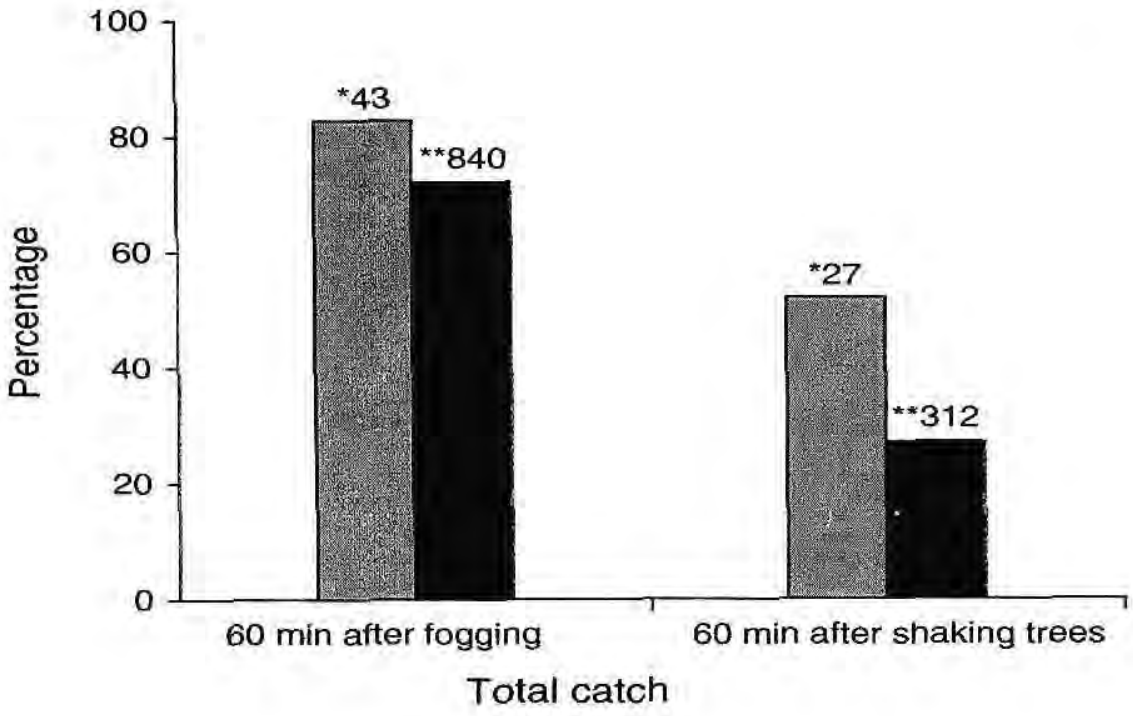

圆 Species ESpecimens * Total of species ** Total of specimens

Figure 1. Percentage of total species and specimens of ants obtained from the canopy $60 \mathrm{~min}$ after fogging and before shaking trees and $60 \mathrm{~min}$ after shaking trees in a Jacareúba (Calophyllum brasiliense) forest plantation near Manaus/Brazil during the rainy season (February, 1992).

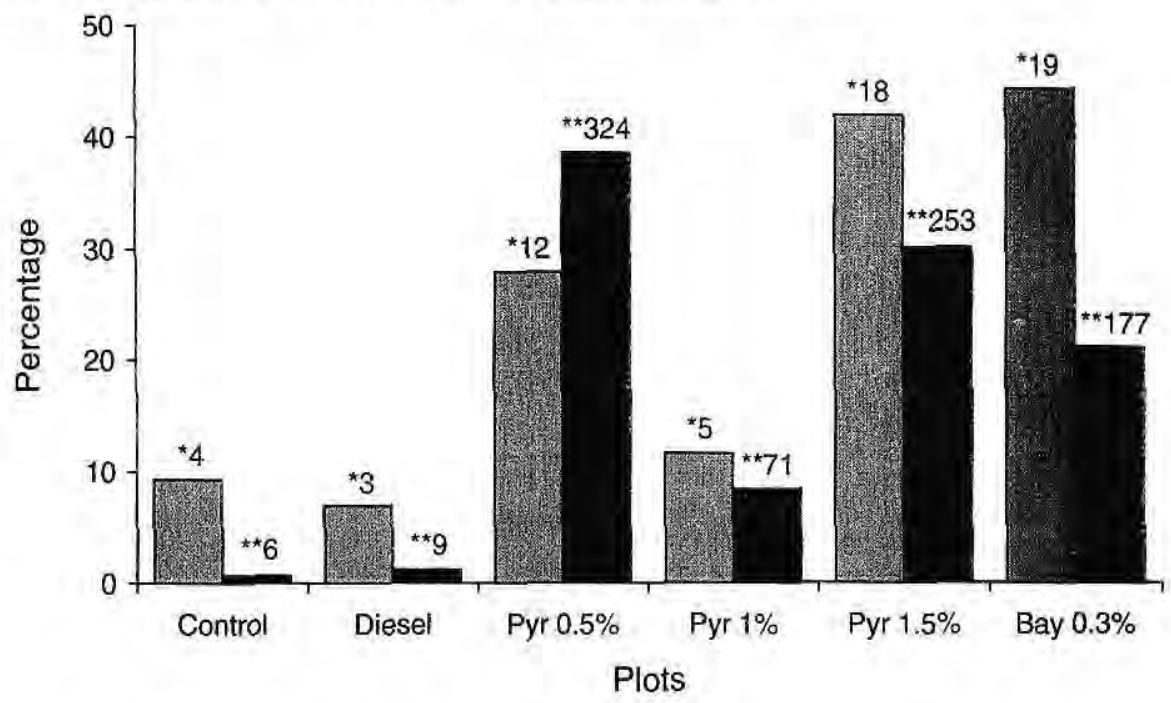

\section{T Species $\mathbf{n}$ Specimens * Total of species ${ }^{* *}$ Total of specimens}

Figure 2. Percentage of total specimens and species of ants obtained from each of six plots $60 \mathrm{~min}$ after fogging the canopy, before shaking trees, in a Jacareuiba (Calophyllum brasiliense) forest plantation near Manaus/ Brazil during the rainy season (February, 1992) with different pyrethrum concentrations and agents. Pyr = natural pyrethrum, without synergist; Bay = synthetic pyrethrum Baythroid, with synergist; Diesel = diesel oil; Control $=$ control plot, no agent used. 


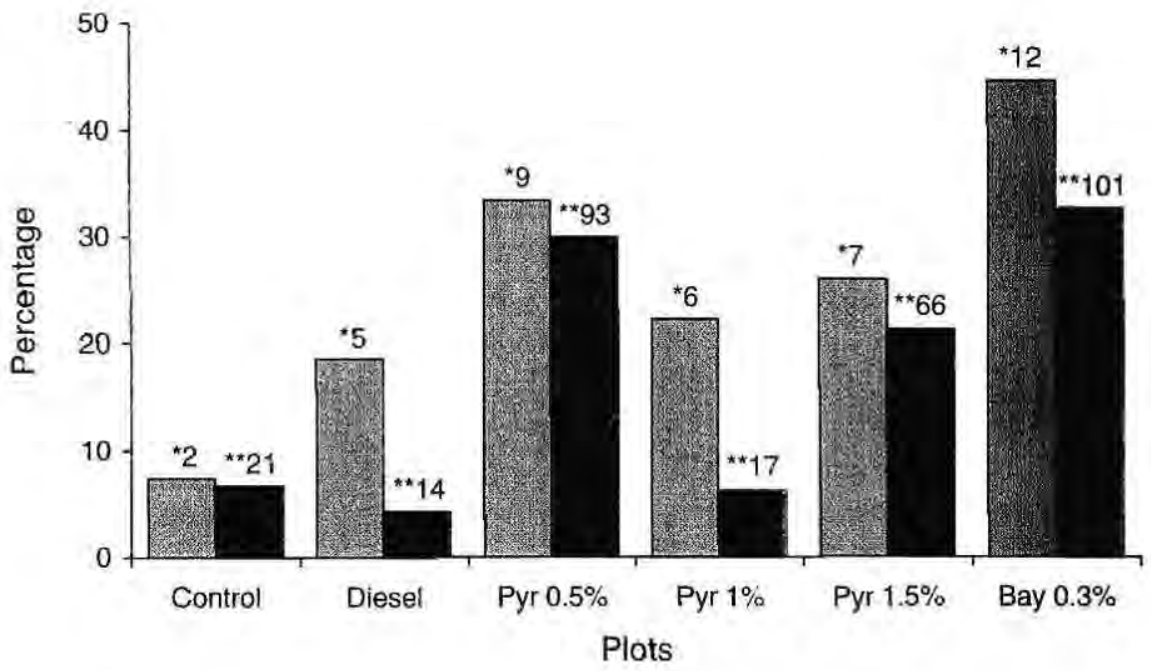

口Species Especimens * Total of species ** Total of specimens

Figure 3. Percentage of total specimens and species of ants obtained from each of six plots 60 min after shaking trees of the fogged canopy in a Jacareúba (Calophyllum brasiliense) forest plantation near Manaus/ Brazil during the rainy season (February, 1992) with different pyrethrum concentrations and agents. Рyr $=$ natural pyrethrum, without synergist, Bay $=$ synthetic pyrethrum Baythroid, with synergist; Diesel $=$ diesel oil; Control $=$ control plot, no agent used.

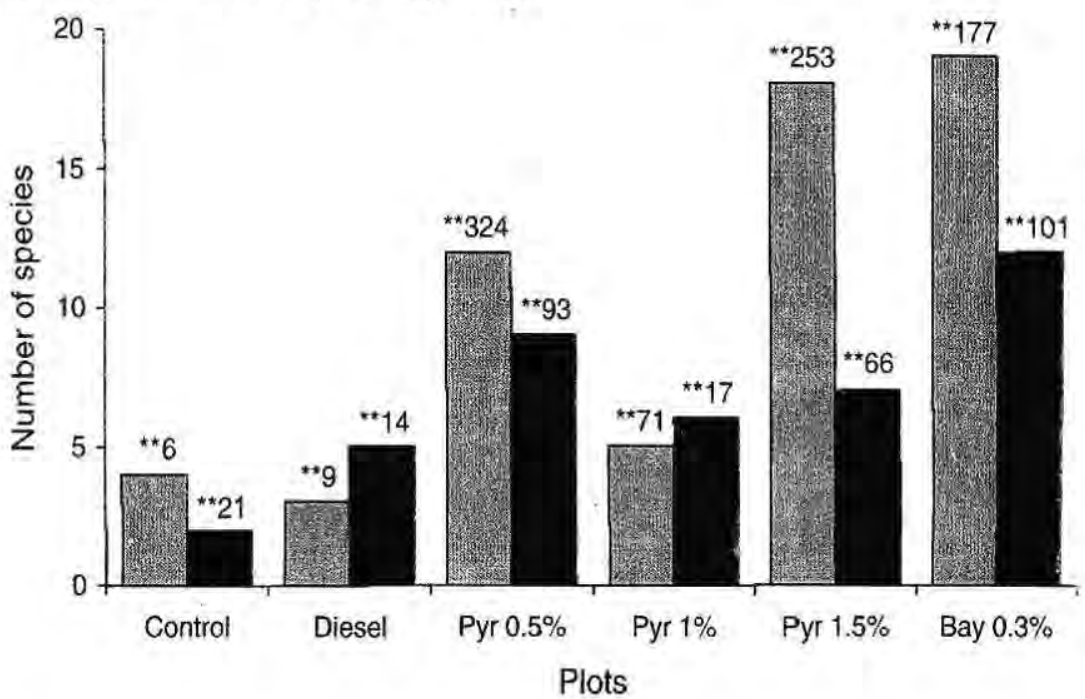

- 60 min after fogging $(\mathrm{N}=840) \quad 60$ min after shaking trees $(\mathrm{N}=312) *$ Number of specimens

Figure 4. Total number of ant species obtained from each of six plots $60 \mathrm{~min}$ after fogging (before shaking trees) and 60 min after shaking trees in a Jacareúba (Calophyllum brasiliense) forest plantation near Manaus Brazil during the rainy season (February, 1992) with different pyrethrum concentrations and agents. Pyr= natural pyrethrum, without synergist; Bay $=$ synthetic pyrethrum Baythroid, with synergist; Diesel = diesel oil; Control $=$ control plol, no agent used. $\mathrm{N}=$ total number of specimens. 


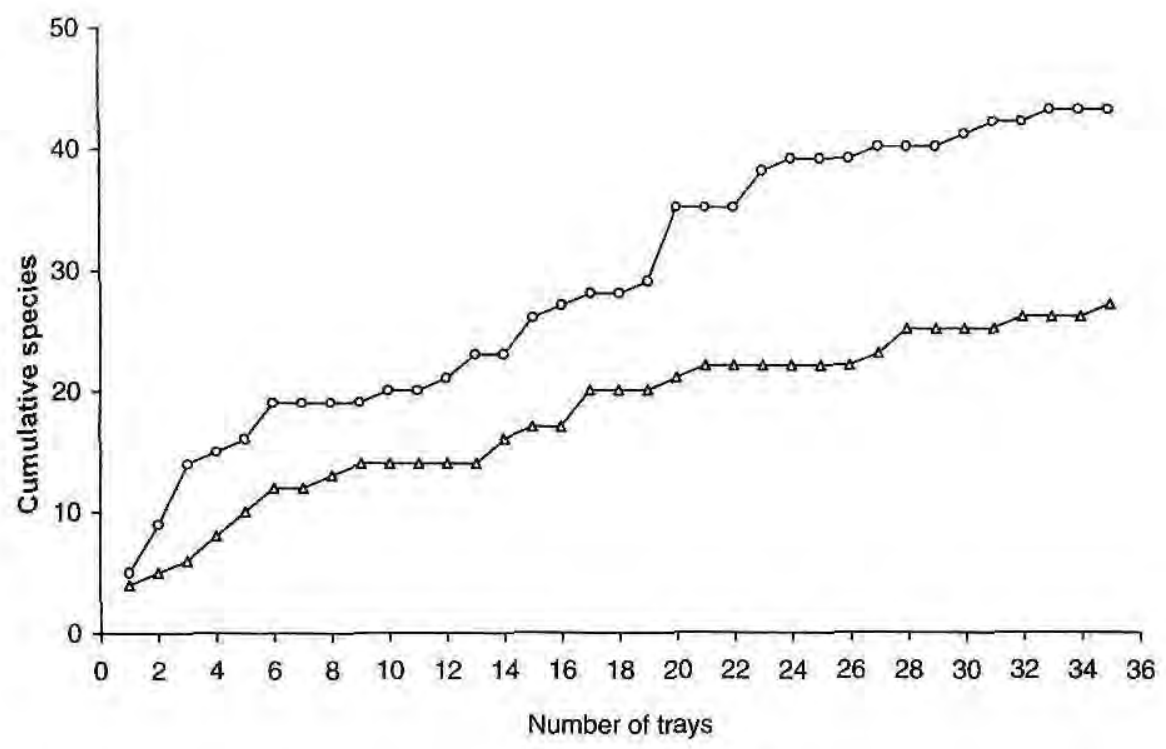

$-0-1$ st hour $\rightarrow-2$ nd hour

Figure 5. Cumulative number of ant species obtained from 35 collecting trays after fogging the canopy of a Jacareúba (Calophyllum brasiliense) forest plantation near Manaus/Brazil during the rainy season (February, 1992). 1 st hour $=60 \mathrm{~min}$ after fogging and before shaking trees; 2 nd hour $=60 \mathrm{~min}$ after shaking trees.

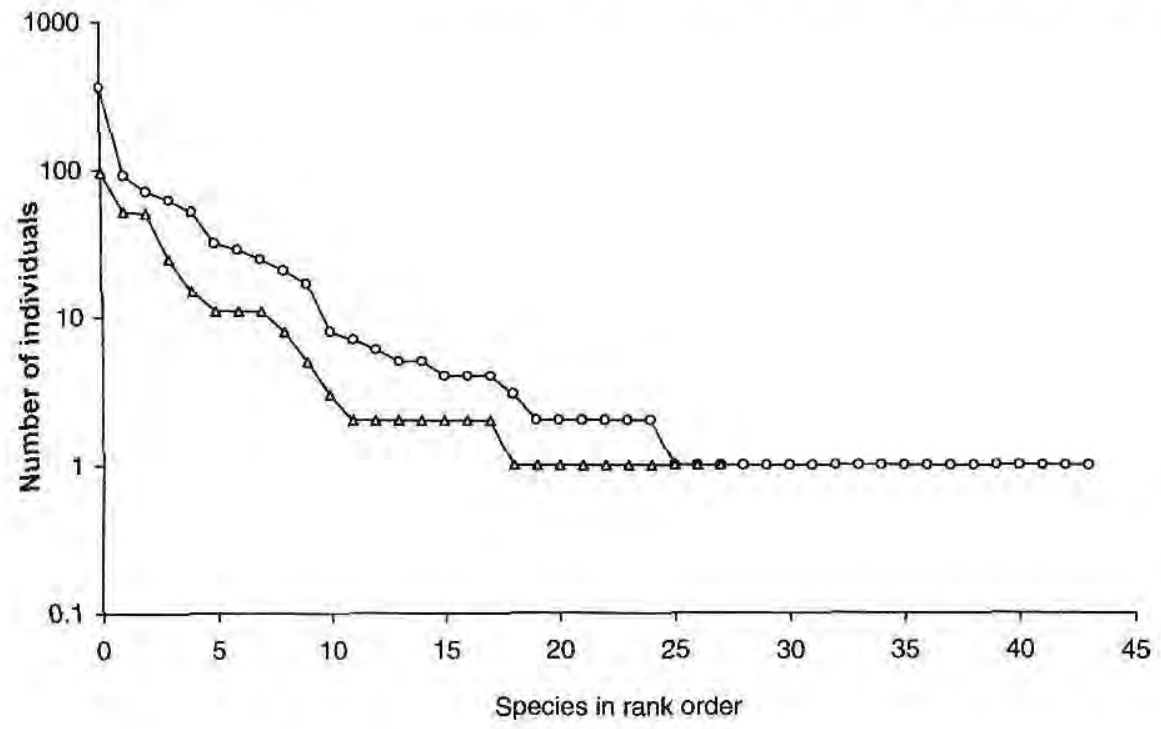

$\rightarrow-1$ st hour $\rightarrow-2$ nd hour

Figure 6. Rank-abundance plots (Whittaker plots, log scale) of ant species based on specimens collected from 36 collecting trays after fogging the canopy of a Jacareúba (Calophyllum brasiliense) forest plantation near Manaus/Brazil during the rainy season (February, 1992). Ist hour $=60 \mathrm{~min}$ after fogging and before shaking trees; 2 nd hour $=60 \mathrm{~min}$ after shaking trees. 


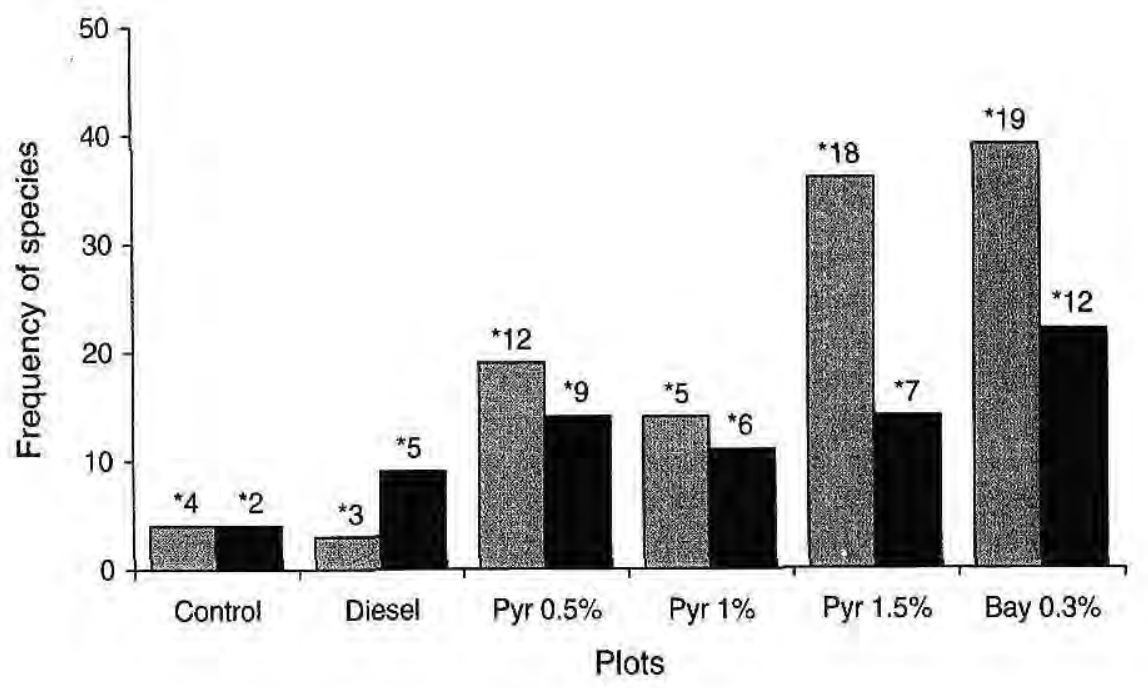

⿴囗玉 60 min after fogging 60 min after shaking trees * Total of species

Figure 7. Frequency of ant species obtained from each of six plots $60 \mathrm{~min}$ after fogging (before shaking trees) and $60 \mathrm{~min}$ after shaking trees in a Jacareúba (Calophyllum brasiliense) forest plantation near Manaus/Brazil during the rainy season (February, 1992) with different pyrethrum concentration and agents. Pyr = natural pyrethrum, without synergist; Bay = synthetic pyrethrum Baythroid, with synergist; Diesel $=$ diesel oil; Control $=$ control plot, no agent used.

of INPA/Univ. Amazonas (February 1992) who joined the canopy fogging studies. Prof. Dr. Wilfried Paarmann, Fachhochschule Hildesheim/Holzminden, Göttingen (Germany) and Dr. Helen Read, Burnham Beeches, Slough (United Kingdom), gave valuable comments which helped to improve the manuscript. Berit Hansen, Tropical Ecology Working Group at the Max-Planck-Institute for Limnology in Plön (Germany), kindly made the drawings.

\section{Literature cited}

Adis, J. 1988. On the abundance and density of terrestrial arthropods in Central Amazonian dryland forests. Journal of Tropical Ecology, 4(1): 19-24.

Adis, J.; Schubart, H.O.R. 1984. Ecological research on arthropods in Central Amazonian forest ecosystems with recom- mendations for study procedures. In: Cooley, J.H.; Golley, F.B. (eds). Trends in Ecological Research for the 1980s. Nato Conference Series I: Ecology, Plenum Press, New York. pp. 111-144

Adis, J.; Lubin, Y.D.; Montgomery, G.G. 1984. Arthropods fromthe canopy of inundated and terra firme forests near Manaus, Brazil, with critical considerations on the pyrethrum-fogging technique. Studies on Neotropical Fauna and Environment, 19(4): 223-236.

Adis, J;; Paarmann, W; Fonseca, C.R.V. da; Rafael, J.A. 1997. Knockdown efficiency of natural pyrethrum and survival rate of living arthropods obtained by canopy fogging in Central Amazonia. In: Stork, N.E.; Adis, J.; Didham, R.K. (eds) Canopy arthropods, 67-81. Chapman \& Hall, London. 67-81

Erwin, T.L. 1983. Tropical forest canopies: the last biotic frontier. Bulletin of the Entomological Society of America, 29(1): 14-19.

Erwin, T.L, 1989. Canopy arthropod biodiversity: 
a chronology of sampling techniques and results. Revista peruana de Entomologia, 32: 71-77.

Harada, A.Y; Adis, J, 1997. The ant fauna of tree canopies in Central Amazonia: a first assessment. In: Stork, N.E; Adis, J.; Didham, R.K. (eds) Canopy arthropods. Chapman \& Hall, London: 382-400.

Hero, J.M. 1990. An illustrated key to tadpoles occurring in the Central Amazonian rainforest, Manaus, Amazonas, Brazil. Amazoniana, 11(2): 201-262.

Höfer, H.; Brescovit, A.D.; Adis, J.; Paarmann, W. 1994. The spider fauna of Neotropical tree canopies in Central Amazonia: first results. Studies on Neotropical Fauna and Environment, 29(1): 23-32.
Penny, N.D.; Arias, J.R. 1982. Insects of an Amazon forest. Columbia University Press, New York, 269 pp.

Prance, G.T. 1990. The floristic composition of the forests of central Amazonian Brazil. In: Gentry, A.H. (ed) Four Neotropical Rainforests. Yale University Press, New Haven. pp. 159-174..

Willis, E.O. 1977. Lista preliminar das aves da parte noroeste e áreas vizinhas da Reserva Ducke, Amazonas, Brasil. Revista Brasileira de Biologia, 37(3): 585-601.

Wilson, E.O. 1987. The arboreal ant fauna of Peruvian forests: a first assessment. Biotropica 19(3): 245-251. 